\title{
Identifying Great Street in Bandung as Part of Bandung Technopolis Concept: a Perception-Based Approach
}

\author{
Dessy Syarlianti ${ }^{\mathrm{a}}$ \\ ${ }^{a}$ Program Study Architecture University Sriwijaya, Jl. Prabumulih Indralaya km 32, Palembang 30100, Indonesia \\ *Corresponding author. Tel.: +62-812-7393255 \\ E-mail address:dessysyarlianti@gmail.com
}

\begin{abstract}
Great Street is required for making a great city. Bandung will develop new City Centre Service (CCS) in Gede Bage with Bandung Technopolis concept which one of the main programs is making Bandung Great Street. It is important to see potencies and problems based on the user perspective so that the concepts will be applicative and effective.

Using the perception-based approach, this paper aims to identify the perception of the street user in Bandung based on their experience in using the streets in Bandung, so it can lead to a contextual concept. From Jacobs's Great Street Criteria, the PPS's criteria and Bandung Great Street criteria can be summarized into five normative variables such as activities, comfortable and amenities, walkability and transportation option, visual attractiveness, and local identity.

The analyzed variables are preferences of the favorite street in Bandung, the reasons, the real usages of the street, the way of using the street, the companion in using the street, and the interesting things. These variables represent all normative variables which combined with three perception variables such as cognitive, affective and conative.

After analyzing the data, it can be concluded that the respondents prefer Ir. H. Djuanda Street, Braga Street, and RE Martadinata Street as the most favorite street, and choose Cihampelas Street as the least favorite street.
\end{abstract}

Keywords: great street; Bandung; environmental preference; perception; Bandung Technopolis

\section{Introduction}

To make a good city requires a good street (Dover \& Massengale, 2014). As a public space, social spaces, commercial spaces, cultural spaces, channels of movement and as symbolic representations of local tradition and culture (Chen \& Chiu, 2006), the street needs to be designed and managed well. The goal is to make a Great Street that can provide various public activities that can evoke strong community along with the stronger local economic. Unfortunately, there are still many people which have not realized that street is very important. Various scholars including (Rapoport, 1977) and (Jacobs, 1993) have recognized the multifunction of a street. The roles of streets in urban life can be summarized as follows: a street is a channel of movement, a communication space, a place of social and commercial encounter and exchange, a place to do business, a political space and a symbolic and ceremonial space in the city (Chen \& Chiu, 2006).

As one of the big cities in Indonesia, Bandung currently has launched Bandung Technopolis conceptual master plan to develop a new City Service Centre. One of the main concepts is to create Bandung Great Street. This concept, unfortunately, has not defined yet which can be seen in the criteria, such as having the sense of community, enhance interaction, accessible, desirable and walkability, which is too general. To make it more efficient and 
applicative requires a pre-design process. It is where the intentions or goals are outlined, a process by which both client and architect or urban designer start to define what these project parameters are (Lee, 2016). It identifies potential problems/ pitfalls, dreams/ goals, the user needs or wants, code and planning requirements, community concerns, functions/ usage, and lifestyle trends. As such, it is a discovery phase. It does not seek to solve everything but it is used as a preliminary guide to inform the design process. For public/ community projects, part of this process may involve extensive public and community because a community believes in a project by taking an active part in the design process.

This paper aims to identify the perception of the street users in Bandung about Great Street character based on their experience by using questionnaire and observation. Therefore, it can lead to the more effective and efficient form of Bandung Great Street concept as part of Bandung Technopolis. The paper is organized into five sections. Section 1 is an introduction, consists of Great Street role in the city, the policy of Bandung Mayor about Bandung Great Street, and the importance of user perception as the basic social context in formulating Bandung Great Street concept. In section 2, we briefly discuss the theory of Great Street, the importance of user perception in design thinking process, and the use of SPSS statistic software (frequencies table and cross table) to analyze data from the questionnaire. Section 3 is about result and interpretation of the analysis based on the perception of Great Street in Bandung. Section 4 is about element of Bandung Great Street. In section 5, the conclusions of the research are drawn.

\section{Great Street Theory}

\subsection{The Great Street Variables}

Alan B Jacobs said there are few factors in designing Great Street, such as places for people to walk with leisure, physical comfort, definition, qualities that engage the eyes, transparency, complementarity, and quality of construction and design (Jacobs, 1993). While Project for Public Space (PPS), a nonprofit planning, design and educational organization which aim to help people create and sustain public space, have some criteria about what makes a Great Street, such as:

1. Access and Linkage. It includes the easiness to cross the street, multiple transportation options, and comfort for the pedestrian on the sidewalk.

2. Uses and Activities. It relates to the variety of function such as restaurants, stores and services, and reason to linger.

3. Comfort and Image. It associates with local and cultural identity, good street furniture, tree and other amenities.

4. Sociability. It associates with the presence of children and seniors, sense of pride and ownership and people gathering.

Bandung Technopolis Conceptual Masterplan also defines Bandung Great Streets in some criteria such as the sense of community, enhanced interaction, accessible, desirable and walkability. These criteria should be implemented in every design of the new street in Bandung nowadays. To make the variable for the questionnaire, these three criteria are summarized to five variables as in this table below.

Table 1. Comparison among Three Criteria of Great Street

\begin{tabular}{lllll}
\hline No & Literature & \multicolumn{1}{c}{ Great Street Criteria } & \multicolumn{1}{c}{ Issues } & \multicolumn{1}{c}{ Normative Variable } \\
\hline 1 & Alan B Jacobs & 1. Places for walk with leisure & 1. Activities & 1. Activities \\
& 2. Physical comfort & 2. Street Furniture & 2. Comfortable \& Amenities (Street \\
& 3. Definition & 3. Comfort & Furniture, trees, etc.) \\
& 4. Qualities that engage the eyes & 4. Walkability & 3. Walkability \& Transportation \\
& 5. Transparency & 5. Corridor Perimeter (building, & option \\
& 6. Complimentary & tree) & 4. Visual attractiveness \\
& 7. Maintenance & 6. Maintenance & 5. Local Identity \\
& 8. Quality of construction and & & \\
& design & & \\
\hline 2 & 1. Access and linkage & 1. Walkability & 2. Transportation option \\
& 2. Uses and activities & &
\end{tabular}




\begin{tabular}{llll}
\hline No & Literature & \multicolumn{1}{c}{ Great Street Criteria } & \multicolumn{1}{c}{ Issues } \\
\hline & & 3. Comfort and image & 3. Activities \\
& & & 4. Local identity \\
& & & $\begin{array}{l}\text { 5. Amenities (street furniture, } \\
\text { tree, etc.) } \\
\text { 6. Visual attractiveness }\end{array}$ \\
& & & 1. Activities \\
& Bandung & Great & 2. Identity \\
& City & & 3. Transportation option \\
& & 2. Enhance interaction & 4. Walkability \\
& & 3. Accessible & \\
& 4. Desirable & 5alkability &
\end{tabular}

\subsection{Role of Environmental Perception in the Design Process}

In the design process, defining and framing the design problem is the key aspect of creativity (Dorst \& Cross, 2001). There are so many ways to define design problem. Environmental perception is one of the important things to consider because it introduces variability (cultural and personal) and modifies the notion of a single environment with invariant properties. Once it is accepted that the user's perceived environment and its positive and negative qualities may be different to the planner's or designer's and that different groups of users may have different perceived environments, then one's approach to understanding the city and the criteria used for design must be different. While the environmental perception has been shown to be important in various fields, in design, it is even more important because of its lower criticality (Rapoport, 1977). So, environments can be shaped with greater freedom than the case with, say, economic decision.

Any attempt to deal with the man-environment interaction must involve three areas such as knowing something, feeling something, and then doing something about it (Rapoport, 1977). There are three broad areas which influence the interaction: (1) cognitive, involving perceiving, knowing and thinking, the basic processes whereby the individual knows his environment, (2) affective, involving feelings and emotions about this environment, motivations, desires and values (embodied in images), and (3) conative, involving acting, doing, striving and thus having an effect on the environment in response to (1) and (2). There are also three aspects in constructing perceived environment, which are: (1) environmental evaluation of preference, perception which is used to describe the evaluation of the environment, i.e., the perception of environmental quality, and hence preference, migration (choice), behavior and decisions, (2) environmental cognition, perception which relates to the way in which people understand, structure and learn the environment and use mental maps to negotiate it, and (3) environmental perception, perception which describes the direct sensory experience of the environment for those who are in it at a given time.

\subsection{Collecting and Analyzing Data}

To collect data, a questionnaire is used which is distributed to a random sample. There are 190 respondents that can be categorized into non-permanent residents (38,9\%) and permanent residents $(61.1 \%)$ of Bandung. Permanent residents are people who have the Residents Identity Card in Bandung and non-permanent ones are people who do not have the Residents Identity Card, including tourist and visitor. Literature study and observation to the object are aimed to see the Great Street aspect and what makes them favorable. To analyze the data, IBM SPSS software is used, especially in table frequencies and cross table, to see the distributions and frequencies of every preference of variables, such as residence status, age, occupation, favorite street, reason of choice, purpose in using the street, companion, way of using the street, and interesting things. 


\section{Identifying Great Street in Bandung}

\subsection{Appraisal of Great Street in Bandung}

The first variable that has been measured is the preference of favorite street in Bandung. This variable represents all of the normative variable, which means that preference for the favorite street in Bandung represents the respondent's perception of Great Street in Bandung. The result shows that both permanent residents and nonpermanent residents have the same preference about the favorite street in Bandung. Around $36.5 \%$ non-permanent residents choose Ir. H. Djuanda (Dago) Street as the most favorite street in Bandung, followed by Braga Street, $31.08 \%$, and RE Martadinata Street, $18.91 \%$. The permanent residents choose Braga Street as the most favorite street with a percentage of $31.03 \%$, followed by Ir. H. Djuanda (Dago) Street, 28.44\%, and RE Martadinata (Riau) Street, 23.27\%. In the other hand, Cihampelas Street is chosen as the least favorite street in Bandung (66.31\%). Overall, the most favorite streets in Bandung are Ir. H. Djuanda Street, Braga Street, and RE Martadinata Street (Table 2).

Table 2. Most Favorite Street in Bandung

\begin{tabular}{lcccc}
\multicolumn{1}{c}{ Street Name } & $\begin{array}{c}\text { Frequ } \\
\text { ency }\end{array}$ & $\begin{array}{c}\text { Percen } \\
\mathrm{t}\end{array}$ & $\begin{array}{c}\text { Valid } \\
\text { Percent }\end{array}$ & $\begin{array}{c}\text { Cumulat } \\
\text { ive } \\
\text { Percent }\end{array}$ \\
\hline Jl. Asia Afrika & 1 & .5 & .5 & .5 \\
\hline $\begin{array}{l}\text { Bonbin menuju arah } \\
\text { sabuga }\end{array}$ & 1 & .5 & .5 & 1.1 \\
\hline Hegarmanah & 1 & .5 & .5 & 1.6 \\
\hline Jalan Soekarno-Hatta & 1 & .5 & .5 & 2.1 \\
\hline Jl. Asia Afrika & 3 & 1.6 & 1.6 & 3.7 \\
\hline Jl. Braga & 59 & 31.1 & 31.1 & 34.7 \\
\hline Jl. Cihampelas & 9 & 4.7 & 4.7 & 39.5 \\
\hline Jl. Ciliwung & 1 & .5 & .5 & 40.0 \\
\hline Jl. Cipaganti & 7 & 3.7 & 3.7 & 43.7 \\
\hline Jl. Dr. Otten dan & 1 & .5 & .5 & 44.2 \\
sekitarnya & 60 & 31.6 & 31.6 & 75.8 \\
\hline Jl. Ir. H. Djuanda (Dago) & 1 & .5 & .5 & 76.3 \\
\hline jl. Merdeka & 1 & .5 & .5 & 76.8 \\
\hline Jl. Purnawarman & 1 & .5 & .5 & 77.4 \\
\hline Jl. Raya Dayeuhkolot & 41 & 21.6 & 21.6 & 98.9 \\
\hline Jl. RE. Martadinata (Riau) & 1 & .5 & .5 & 99.5 \\
\hline Jl. Sersan Bajuri & 1 & .5 & .5 & 100.0 \\
\hline Jl. supratman diponegoro & 190 & 100.0 & 100.0 & \\
\hline & Total & 190 & & \\
\hline
\end{tabular}

Table 3. Most Favorite Street Based on Residential Status

\begin{tabular}{|c|c|c|c|}
\hline \multirow[b]{2}{*}{ Street in Bandung } & \multicolumn{2}{|c|}{ Residential status } & \multirow[b]{2}{*}{ Total } \\
\hline & $\begin{array}{c}\text { Non- } \\
\text { permanent }\end{array}$ & $\begin{array}{c}\text { Permane } \\
\mathrm{nt}\end{array}$ & \\
\hline Jl. Asia Afrika & 0 & 1 & 1 \\
\hline $\begin{array}{lll}\begin{array}{l}\text { Bonbin } \\
\text { sabuga }\end{array} & \text { menuju arah } \\
\end{array}$ & 0 & 1 & 1 \\
\hline Hegarmanah & 0 & 1 & 1 \\
\hline Jalan Soekarno-Hatta & 1 & 0 & 1 \\
\hline Jl. Asia Afrika & 0 & 3 & 3 \\
\hline J1. Braga & 23 & 36 & 59 \\
\hline Jl. Cihampelas & 6 & 3 & 9 \\
\hline J1. Ciliwung & 1 & 0 & 1 \\
\hline Jl. Cipaganti & 0 & 7 & 7 \\
\hline $\begin{array}{lccc}\text { J1. } & \text { Dr. } & \text { Otten } & \text { dan } \\
\text { sekitarnya } & & \\
\end{array}$ & 1 & 0 & 1 \\
\hline Jl. Ir. H. Djuanda (Dago) & 27 & 33 & 60 \\
\hline jl. Merdeka & 0 & 1 & 1 \\
\hline Jl. Purnawarman & 0 & 1 & 1 \\
\hline Jl. Raya Dayeuhkolot & 1 & 0 & 1 \\
\hline $\begin{array}{ll}\text { Jl. } & \text { RE. } \\
(\text { Riau })\end{array}$ & 14 & 27 & 41 \\
\hline Jl. Sersan Bajuri & 0 & 1 & 1 \\
\hline Jl. supratman diponegoro & 0 & 1 & 1 \\
\hline Total & 74 & 116 & 190 \\
\hline
\end{tabular}




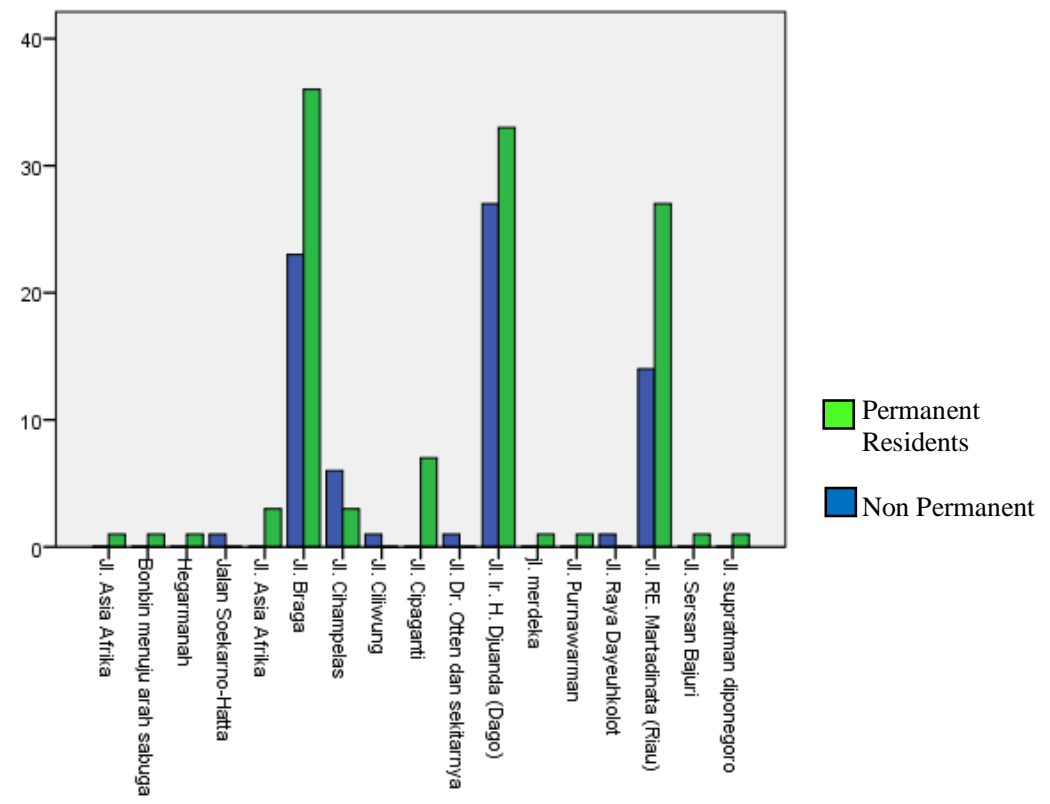

Figure 1. Comparison of Favorite Street Based on Residential Status
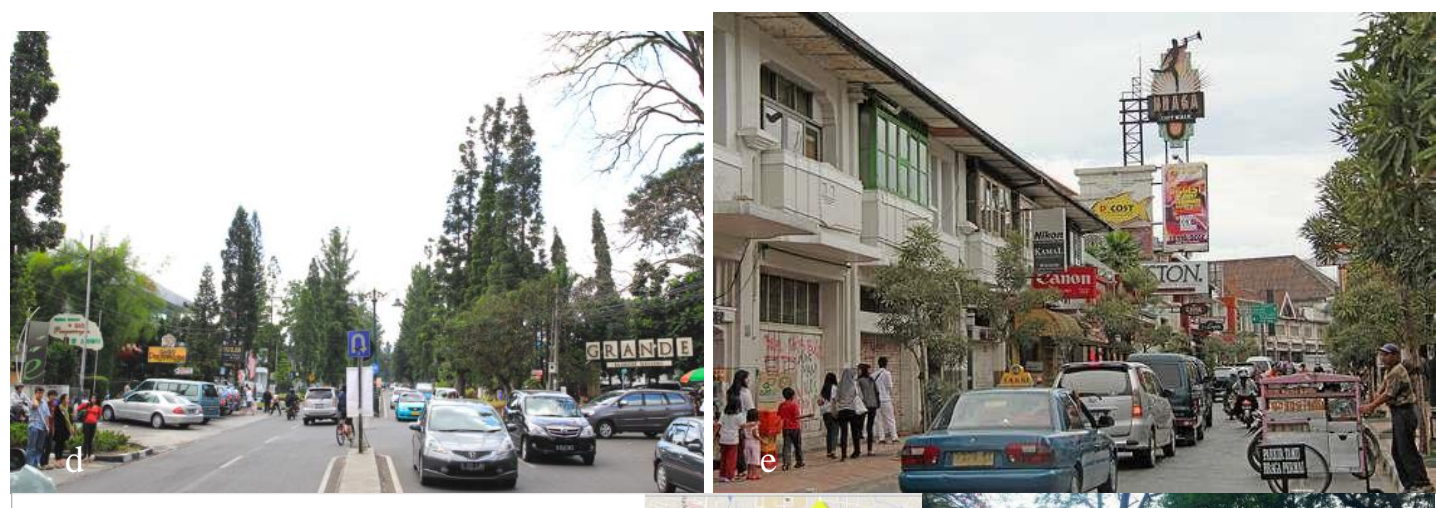

\section{PETA}

\section{N D O N E S I A}

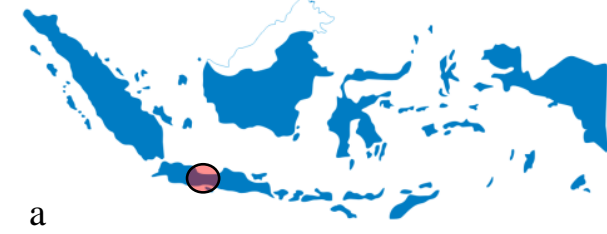

b
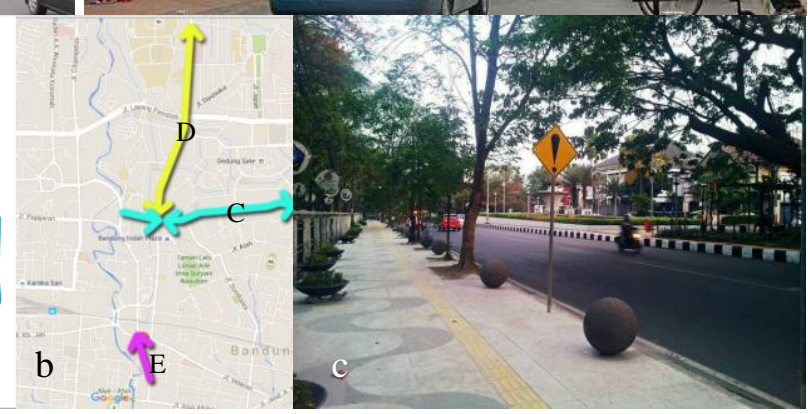

Figure 2. (a) Location of Bandung in Indonesia Map; (b) Location of Favorite Street in Bandung Map; (c) RE Martadinata Street; (d) Ir. H. Juanda Street; (e) Braga Street

\section{Ir. H Djuanda Street}

This street is also known as Dago Street among the locals. It has several potencies such as colonial architecture style, wide sidewalks, and a lot choice of shopping and culinary tour, which makes it as one of 
the unique identities of Bandung. Having $7.36 \mathrm{~km}$ length, it has status as an arterial secondary road with two-way directions and four lanes.

\section{Braga Street}

Braga Street is very popular in Bandung since its establishment in the colonial era. Shopping merchants are placed on both sides of the street which have the unique architecture which resembles old European model, like Paris, which is preserved from 1920 until today. Due to this reason, this street contributes greatly in making the famous nickname for Bandung which is 'Paris van Java'. Another nickname for Bandung, Kota Kembang or Flower City, is emerged also from this street. This street only has a short length, which is 700 meters with one-way direction and two lanes.

\section{RE Martadinata Street}

RE Martadinata Street is also known as Riau Street among locals. It has $3.29 \mathrm{~km}$ length, two-way directions, and four lanes. This street is one of the shopping street icons in Bandung, which is indicated by many shopping merchants, known as factory outlet, on both sides of the street.

\subsection{The Reason for Choosing the Street}

There are many reasons by respondents in choosing the street, and most of them tell more than one reason. The reasons for choosing Ir. H. Djuanda (Dago) Street are lush trees, strategic place, and friendly pedestrian sidewalk. Braga Street is chosen because of having a friendly pedestrian sidewalk and unique architecture style. While RE Martadinata Street is chosen because of its pedestrian-friendly sidewalks and lush trees. The most favorite reason for choosing Great Street in Bandung is having a friendly pedestrian sidewalk, which is dominated by Braga Street. It means that respondents judge Great Street in Bandung by its sidewalks, which can be used by walking or bicycling.

Table 4. The Reason for Choosing the Favorite Street

\begin{tabular}{|c|c|c|c|c|c|c|c|c|c|c|}
\hline No. & Street Name & $\begin{array}{l}\text { Variety } \\
\text { of Food }\end{array}$ & $\begin{array}{l}\text { Fashion } \\
\text { Shop }\end{array}$ & $\begin{array}{l}\text { Lush } \\
\text { Trees }\end{array}$ & $\begin{array}{l}\text { Friendly } \\
\text { Sidewalk }\end{array}$ & $\begin{array}{l}\text { Wide } \\
\text { Street } \\
\text { Parking }\end{array}$ & $\&$ & $\begin{array}{l}\text { Unique } \\
\text { Architecture }\end{array}$ & Strategic & Total \\
\hline 1 & Ir. H. Djuanda Street & 23 & 17 & 35 & 29 & 7 & & 7 & 29 & 147 \\
\hline 2 & Braga Street & 15 & 4 & 8 & 53 & 5 & & 49 & 14 & 148 \\
\hline \multirow[t]{2}{*}{3} & RE Martadinata Street & 15 & 12 & 23 & 28 & 6 & & 6 & 14 & 104 \\
\hline & & 53 & 33 & 66 & 110 & 18 & & 62 & 57 & \\
\hline
\end{tabular}

\subsection{The Real Usage of the Chosen Street}

To see the comparison among the perceptions of the Great Street by respondents, the real usages of the street are needed to be identified. The respondents for Dago Street use the street as a pass-through way (33.3\%) and culinary tour $(30 \%)$. The culinary tour is also the most popular purpose in Braga Street with $54.2 \%$ and RE Martadinata Street with $51.2 \%$. It means that the most popular usage of the Great Street in Bandung is for the culinary tour $(44.37 \%)$, followed by as a pass-through way $(26.87 \%)$.

Table 5. Purpose of Using the Street

\begin{tabular}{lcccc}
\hline & \multicolumn{3}{c}{ Favorite Street in Bandung } \\
Purpose in using the street & Braga Street & St. Djuanda (Dago) & $\begin{array}{c}\text { RE. Martadinata } \\
\text { (Riau) Street }\end{array}$ & Total \\
\hline Everything on Braga Street & 1 & 0 & 0 & 1 \\
Car Free Day (CFD) event & 0 & 1 & 0 & 1 \\
School location & 0 & 1 & 0 & 1 \\
Enjoying the atmosphere & 4 & 0 & 0 & 4 \\
As a lane to another place & 15 & 20 & 8 & 43 \\
Working place & 0 & 1 & 0 & 1
\end{tabular}




\begin{tabular}{lcccc} 
Home & 1 & 8 & 0 & 9 \\
Training & 0 & 1 & 0 & 1 \\
Architecture tour & 1 & 0 & 0 & 1 \\
Shopping tour & 3 & 9 & 12 & 24 \\
Photography tour & 2 & 0 & 0 & 2 \\
Culinary tour & 32 & 18 & 21 & 71 \\
Culinary and shopping tour & 0 & 1 & 41 & 1 \\
& 59 & 60 & & 160 \\
\hline
\end{tabular}

\subsection{The Way of Using the Street}

The way of using the street by the respondents is also analyzed to see the character of most users in the favorite street. Based on the questionnaire, the most favorite way of using the street is by using personal motorized vehicles (46.87\%), especially in Dago Street and Riau Street. Walking (45\%) is the most popular way of using Braga Street. Some of these results are in contrary with the reason of choosing the street in Table 2. Dago Street is chosen because of lush trees and friendly sidewalks in spite of the use of the street using vehicles by most of the users, which is rather difficult to enjoy the quality of tree and sidewalk. In Braga Street, the result is consistent. Most of the users prefer to walk to enjoy the quality of pedestrian friendly sidewalk and unique architecture style. In Riau Street, it is dominated by the use of personal vehicles as a way to reach the destination for the culinary tour.

\begin{tabular}{|c|c|c|c|c|}
\hline & \multicolumn{3}{|c|}{ Favorite Street in Bandung } & \multirow[b]{2}{*}{ Total } \\
\hline & $\begin{array}{l}\text { Braga } \\
\text { Street }\end{array}$ & $\begin{array}{c}\text { Ir. H. Djuanda } \\
\text { (Dago) Street }\end{array}$ & $\begin{array}{l}\text { RE. Martadinata } \\
\text { (Riau) Street }\end{array}$ & \\
\hline & 0 & 1 & 2 & 3 \\
\hline On foot & 42 & 16 & 14 & 72 \\
\hline Using personal motorized vehicle & 15 & 36 & 24 & 75 \\
\hline Using public transportation & 1 & 5 & 1 & 7 \\
\hline Using bicycle & 1 & 2 & 0 & 3 \\
\hline & 59 & 60 & 41 & 160 \\
\hline
\end{tabular}

\subsection{The Companion in Using the Street}

Another variable is the companion in using the street, whether the respondents go along the street by himself, with friends, or with families. This variable indicates perception in enjoying the street, just like in PPS's Great Street criteria, where one of the criteria of sociability is the presence of children and seniors. The more people like to spend time in the street with family, the more sociable and comfortable the street. Most of the respondents like to go along with friends (43.12\%), especially in Braga Street and with families (30.6\%), especially in Dago Street. If we look at the ages of the respondents with families, it is indicated that most of the families are the young ones. It should affect to the proportion of facilities that should be fulfilled.

Table 7. Companion in Using the Street

\begin{tabular}{lcccc}
\hline & \multicolumn{3}{c}{ Favorite Street in Bandung } & \\
\cline { 2 - 4 } Companion & Braga Street & $\begin{array}{c}\text { Ir. H. Djuanda } \\
\text { (Dago) Street }\end{array}$ & $\begin{array}{c}\text { RE. Martadinata } \\
\text { (Riau) Street }\end{array}$ & Total \\
\hline Subordinate & 0 & 0 & 1 & 1 \\
Family & 0 & 0 & 1 & 1 \\
Friend & 16 & 18 & 15 & 49 \\
All answers & 33 & 22 & 14 & 69 \\
Alone & 0 & 2 & 0 & 2 \\
Total & 10 & 18 & 10 & 38 \\
\hline
\end{tabular}


Table 8. Cross table of User Age and Companion

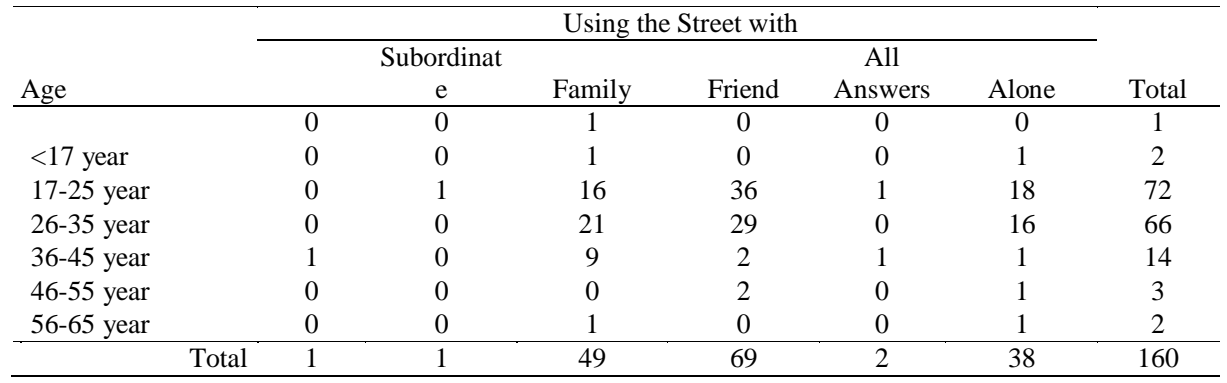

\subsection{The Most Interesting Thing of the Street}

The last variable is the interesting thing of the street. Dago Street is rated for trees and park (23.33\%), while Braga Street (28.75\%) and Riau Street (26.82\%) is rated for architecture style. Most of the respondents (43.75\%) choose style of architecture and street furniture (16.25\%) as the most interesting thing in the street. It means that streets in Bandung nowadays have potencies in comfort and image criteria to create Great Street.

Table 9. The Most Interesting Thing of the Street in Bandung

\begin{tabular}{|c|c|c|c|c|}
\hline \multirow[b]{2}{*}{ Most Interesting Thing } & \multicolumn{3}{|c|}{ Favorite Street in Bandung } & \multirow[b]{2}{*}{ Total } \\
\hline & Braga Street & $\begin{array}{l}\text { Ir. H. Djuanda } \\
\text { (Dago) Street }\end{array}$ & $\begin{array}{l}\text { RE. Martadinata } \\
\text { (Riau) }\end{array}$ & \\
\hline $\begin{array}{l}\text { Pedestrian facilities (sidewalk, } \\
\text { bus stop, handicapped / disabled } \\
\text { access, zebra cross, etc.) }\end{array}$ & 3 & 12 & 9 & 24 \\
\hline Variety of activities & 1 & 8 & 7 & 16 \\
\hline $\begin{array}{l}\text { Neat and well maintained } \\
\text { corridor }\end{array}$ & 1 & 0 & 0 & 1 \\
\hline Spacious parking lot & 0 & 1 & 1 & 2 \\
\hline Street vendors & 0 & 3 & 1 & 4 \\
\hline Trees and parks & 1 & 14 & 2 & 17 \\
\hline Street furniture & 7 & 9 & 10 & 26 \\
\hline Architecture style & 46 & 13 & 11 & 70 \\
\hline Total & 59 & 60 & 41 & 160 \\
\hline
\end{tabular}

\subsection{The Problems of the Street}

From the questionnaire, several respondents choose the three most favorite streets as non-favorite ones. The perception can be used as a suggestion to improve the quality of Great Street in Bandung. Most problems in Braga Street is about aridity, narrow street, and parking difficulty. In Dago Street, some of the respondents do not like the street because of aridity, as seen as the inverse from the Table 1, where most of the respondents like the street because of its lush trees. In Riau Street, the problems are the aridity, narrow sidewalks, and street vendors. 
Table 10. The Problems of the Street in Bandung

\begin{tabular}{lccccc}
\hline & \multicolumn{4}{c}{ Street in Bandung } & \\
\cline { 2 - 5 } & $\begin{array}{c}\text { Braga } \\
\text { Street }\end{array}$ & $\begin{array}{c}\text { Cihampelas } \\
\text { Street }\end{array}$ & $\begin{array}{c}\text { Ir. H. Djuanda } \\
\text { (Dago) Street }\end{array}$ & $\begin{array}{c}\text { RE. } \\
\text { Martadinata } \\
\text { (Riau) Street }\end{array}$ & Total \\
\hline $\begin{array}{l}\text { Monotonous buildings } \\
\text { Too many street vendors }\end{array}$ & 0 & 0 & 1 & 0 & 1 \\
Aridity & 6 & 6 & 0 & 2 & 8 \\
Narrow street and parking & 7 & 22 & 5 & 3 & 36 \\
lot & 0 & 22 & 2 & 1 & 32 \\
Not strategic location & 1 & 5 & 1 & 0 & 1 \\
Traffic jam & 0 & 1 & 1 & 1 & 8 \\
Limited choice of food & 0 & 70 & 0 & 0 & 1 \\
vendors & 14 & 126 & 2 & 3 & 75 \\
Narrow sidewalk & Total & 14 & 12 & 10 & 162 \\
\hline
\end{tabular}

\section{Perception of Bandung Great Street Element}

Based on the findings, people tend to evaluate street in Bandung as a great street with these three factors of perception:

1. Cognitive (knowing)

The first thing people in Bandung recognize as a great street is if it has a large sidewalk. The larger sidewalk, the better people value it as a great street. It is due to the spatial requirement known by seeing it without needing to experience it. People can see it from a moving car, from the photograph, or something else. The sidewalk is central of a Great Street, so it should represent all of the greatness of the street. In order to make a Great Street, we should provide a great sidewalk.

2. Affective (feeling)

This factor relates to the sense or feeling of someone to the street. People tend to experience the thermal comfort and the street view as part of a great street in Bandung. The more comfort of the thermal condition and the more diverse of the street view, the better value increase of a great street. To make a great street feeling, we should consider the thermal comfort. In Indonesia, the maximum thermal comfort in public space is about $27-28^{\circ} \mathrm{C}$, which could be implemented, for example, in trees density alignment, building density, and street dimension. In street view, we can provide more green space as people prefer streetscapes with views of green spaces (Rolo and Barker, 2013). We could also consider economic, social, and cultural value about the area to make the visual sequence that emphasizes its characteristic.

3. Conative (doing)

This factor relates to the activity that most people like to do on a great street. In Bandung, the basic need activities, especially the one which is done in groups, influence the perception of people about Great Street. The examples of these activities are eating and social interaction. So, to make a great street, we should design the facility which uses 'group dimension', such as the bench, sidewalk dimension, and other street furniture and design sidewalk that provides social interaction. Besides that, there are also the significant streetscape features that encourage pedestrian traffic volumes in the street, such as the number of pieces of street furniture, the proportion of windows on the street, and the proportion of active street frontage (Ewing and Hajrasouliha, 2015).

There is also inconsistency between respondents about what they think (cognitive) and what they do (conative). Based on the research, most people choose the sidewalk as a reflection of a great street. But, in reality, most of them use vehicles on the street, which tends to be quite difficult to enjoy the sidewalk from the vehicles. It means people already recognize the kind and the benefit of using Great Street with walking but they still prefer to use the vehicle. The problems for people to choose walking in great street in Bandung are:

1.Long distance between home and workplace make people prefer to use their vehicles than walking

2. Discontinuity and bad quality of public transportation 
3. Uncomfortable sidewalks

4. Fast traffic in street

So, the implementation of Bandung Great Street concept, as part of Bandung Technopolis development, will hard to achieved unless the problems are solved.

\section{Conclusion}

In this study, there are few conclusions about Great Street perception among respondents in Bandung. First, there is little different perception from permanent and non-permanent residences in rating Great Street in Bandung. To identify the cause of the difference, there should be other comprehensive research regarding historical and social background influence. Second, respondents evaluate Great Street mostly at sidewalk position, looking especially at trees and park along with the architecture style to see whether it is a Great Street or not. Third, the potencies of Great Street function in Bandung are now seen as the culinary tour and a pass-through way. Fourth, most respondents enjoy the street in a group, whether with friends or family, instead of being alone. And last, there is inconsistency preference of the respondents in the way of using Great Street. The analysis shows that most of them choose their favorite street because of the sidewalk, in spite of using their own vehicles while passing through the street. It is quite difficult to enjoy the sidewalk from inside the vehicles. For some considerations, the problems of the three streets, such as aridity, narrow sidewalk, and street vendors also need to identify. The problem of this research is the variation of length among the streets. The longer the street, the wider perception of the respondents. It is because of the difference characteristic from the start point to the end point. Hopefully, this conclusion can be considered as part of the preliminary design process in making Bandung Great Street concept.

\section{References}

Chen, C.-H., \& Chiu, M.-L. (2006). SCALE - a street case library for environmental design with agent interfaces. In Innovations in Design \& Decision Support Systems in Architecture and Urban Planning (pp. 137-150). Dordrecht: Springer.

Dorst, K., \& Cross, N. (2001). Creativity in the design process: co-evolution of problem-solution. Design Studies, 22(5), $425-437$. https://doi.org/10.1016/S0142-694X(01)00009-6

Dover, V., \& Massengale, J. M. (2014). Street design : the art and practice of making complete streets. New Jersey: Wiley \& Sons.

Jacobs, A. B. (1993). Great streets. New York: MIT Press.

Rapoport, A. (1977). Human aspects of urban form : towards a man-environment approach to urban form and design. Oxford: Pergamon Press. 